\title{
Impact of nano additives on electroless nickel phosphorous (EN-P) coating
}

\author{
M. Mumtaz Mirza ${ }^{1}$, Elansezhian Rasu ${ }^{1 *}$ and Anjali Desilva ${ }^{2}$ \\ ${ }^{1}$ Faculty of Mechanical \& Industrial Engineering, \\ Caledonian College of Engineering, Muscat, Oman, \\ ${ }^{2}$ Built \& Natural Environment Dept, Glasgow Caledonian University, U.K. \\ Phone: +96896174439 \\ *Email: mumtaz@caledonian.edu.om; mumtazyousafi2000@gmail.com
}

\begin{abstract}
An experimental work has been carried out to identify the impact and evaluation of various Nano additives in Electroless Nickel-Phosphorous (EN-P) bath. Different coatings were developed through EN-P bath on ASTM A106 B substrate influenced with Nano additives. The bath consisted of Nickel Sulphate (26 g/L), Sodium Hypo-Phosphite $(30 \mathrm{~g} / \mathrm{L})$ as the reducing agent, sodium acetate $(16 \mathrm{~g} / \mathrm{L})$ as the stabiliser and Ammonium Hydrogen Di Fluoride ( $8 \mathrm{~g} / \mathrm{L})$ as the complexing agent. Nano additives such as $\mathrm{ZnO}$, $\mathrm{Al}_{2} \mathrm{O}_{3}$ and $\mathrm{CuO}$ were added at various concentrations of $0.1 \%, 0.5 \%, 1 \%$, and $2 \%$ in the EN-P bath and their influences on coating process characteristics were studied. The output parameters such as mechanical, characterisation and corrosion resistance evaluations were measured. The investigation proved that the suggested method resulted in substantial improvement on the quality of the coatings developed. The evaluation was reported at $1 \%$ concentration of Nano additives in the bath. The overall performance of Nano $\mathrm{Al}_{2} \mathrm{O}_{3}$ in the En-P bath resulted in significant improvement on the corrosion resistance and quality of the coating produced as compared to other Nano additives.
\end{abstract}

Keywords: Nano additives; corrosion; concentration; tribology; surface morphology; low alloy steel.

\section{INTRODUCTION}

Corrosion is the oxidative process between the environment and the substrate due to an electrochemical reaction [1]. To isolate the pipeline surface from corrosion, researchers attempted different techniques to stop corrosion that included protective coatings on the pipeline surface. In the present scenario, oil pipelines using fusion bonded epoxy (FBE) or a three-layered polyolefin (3LPO) (polyethylene or polypropylene) coatings brittleness in coatings was developed, resulting in the formation of cracks [1-3]. Electroless Nickel phosphorous (EN-P) coating is one of the popular techniques used worldwide in industrial application with positive results [2]. However, in the oil and gas industry, very little has been incorporated until now [3]. One of the advantages of EN-P coating is, due to its auto catalytic reaction, a uniform coating is deposited on irregular surfaces, resulting in the formation of less porous deposits, high hardness, better resistance to wear, abrasion and most importantly provides resistance to corrosion [4, 5]. All smooth surfaces possess some degree of roughness, as it may cause friction, wear, drag and fatigue, but on the other hand, it is also beneficial as it allows surfaces to trap lubricants and avoids them from bonding together. The concept of adding Nano additives in the EN-P coating will 
provide adequate results. As shown in Figure 1, the Nano additives sit in the gaps of the molecular structure of the coating, thus, improve not only the corrosion resistance but on the other hand also provide good surface finish and micro hardness [6]. Amalgamation of Nano additives in the EN-P bath has also been tried to a larger extent. A benefit of using Nano additives in the EN-P bath is, when the right concentration of Nano additives is added in the coating, they spread and dissolve uniformly due to their high volume to surface area since the particle sizes considered will be from 40 to $100 \mathrm{~nm}$. These Nano particles sit in the molecular structure gap of the coating and do not allow oxidation to take place.
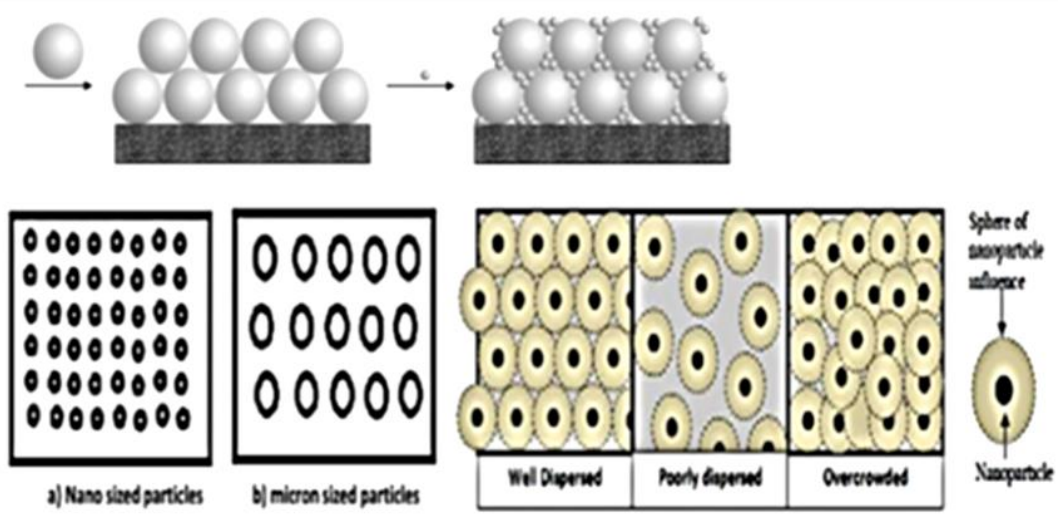

Figure 1. Configuration of Nano additives in substrate molecular structure [7].

It is known that EN-P coating contains Nickel ions employing sodium hypophosphite as the reducing agent (RA). When sodium hypophosphite is used as a RA in EN plating, a typical composition for the deposit ranging from 92 to $95 \%$ Nickel and 6 to $8 \%$ phosphorus is formed. The Nickel deposit as metal gives strength to the coating and Phosphorous on the other hand will provide corrosion resistance. In the En-P bath, the phosphorous is going to be deposited and its range is varied from 3 to $12 \%$. For this bath, medium concentration of Phosphorous is deposited ranging from 6 to $9 \%$ [8]. It is clear that the medium phosphorus deposits provide better corrosion resistance which is the primary goal but on the other hand there are considerable wear properties in the asdeposited condition and this would naturally be attributed to greater hardness [2,9].

In this investigation, Nano particles chosen are from oxide group i.e., $\mathrm{CuO}, \mathrm{Al}_{2} \mathrm{O}_{3}$ and $\mathrm{ZnO}$ [4]. These oxides form a passive layer on the coating surface, thus preventing corrosion. Moreover, the dissolved Nano particles reduce the direct exposure of the coating area to the environment, resulting in lesser reaction on the surface and hence less weight loss. These Nano additives will work like solid particles, thus, reducing high ambient temperature effect on coatings and also improving the surface finish and hardness. In 1844, Wurtz established that the metallic Nickel could be deposited from an aqueous solution by reduction with hypophosphite [7], but the metal which was formed was in powder form. Later, Apachitei [10], and Mandich and Krulik [11] worked on bright coatings in a reaction vessel when the reducing agent was added. However, these baths decomposed naturally and formed deposits on surface that interacted with the solution, even on the walls of the container. Other investigators analysed the process but their interest revolved around the chemical reaction instead of the plating process. In 1946, electroless Nickel technology was discovered as it is used today by Brenner et al. [12]. He was the first to refer the process as 'Electroless'. Some of the main characteristics of EN-P coatings are excellent corrosion and wear resistance, better uniformity and 
thickness, good solder ability, and improved mechanical and physical properties [15]. The current trend is mostly focused on improving the tribological as well as mechanical properties of the EN-P coatings that cover fundamental aspects like Nickel recovery efficiency (NRE), addition of reducing agents, varying EN bath compositions and techniques through surfactants, special treatments and improving mechanical properties [13]. The coating quality of attaining EN-P deposit on the substrate is determined by many factors such as temperature, $\mathrm{pH}$ value of the bath, loading of the bath, concentrations of Nickel and the reducing agent and surface properties of the substrate $[14,15]$. Despite the complex behaviour of the deposition reactions, qualitative discussions on the effects of added Nano additives such as $\mathrm{Al}_{2} \mathrm{O}_{3}, \mathrm{CuO}$, and $\mathrm{ZnO}$ that would affect surface roughness, surface morphology, micro hardness, specific wear rate, and wear morphology are presented. These parameters were investigated at various concentrations of Nano additives in the EN-P bath and at the end, based on the investigation, the evaluated concentration was identified and reported in this paper [16-20].

\section{METHODS AND MATERIALS}

\section{Experimental Set Up}

Experimental work was done under EN-P bath with Nano additives of $\mathrm{Al}_{2} \mathrm{O}_{3}, \mathrm{CuO}$ and $\mathrm{ZnO}$ size ranging from 40 to $50 \mathrm{~nm}$ [21]. Different Nano additive concentrations of 0.5 , $1,1.5$ and $2 \%$ in the bath were tried to determine the best concentration performance. Samples of size $20 \times 20 \times 7 \mathrm{~mm}^{3}$ were prepared from ASTM A106B low alloy steel [22] as used in gulf oil pipelines. The samples before putting up in the bath were cleaned through mechanical and chemical polishing [23] as shown in Figure 2.

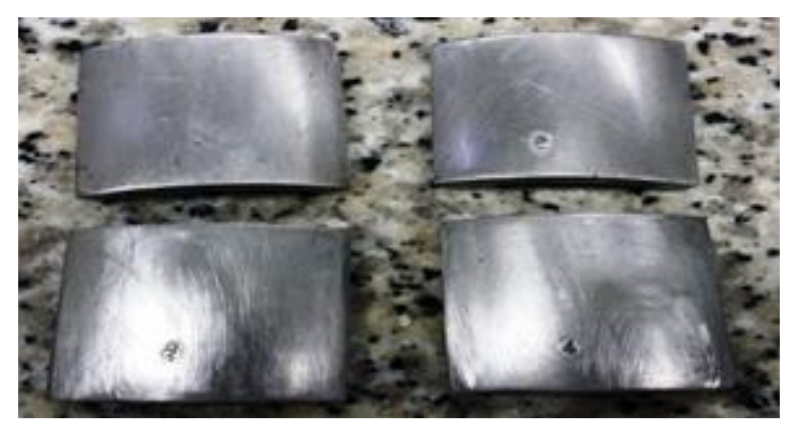

Figure 2. Samples after mechanical \& chemical polishing.

\section{Preparation of EN-P bath}

The mechanism in EN-P bath contained different reactions which were not properly justified by the researchers [9]. It has been assumed that the reaction developed on the anodic and cathodic polarities that was proved in terms of the deposition on the surface of the substrate. The mechanism explained the following reactions [24]:

$$
\begin{aligned}
& 3 \mathrm{NaH}_{2} \mathrm{PO}_{2}+3 \mathrm{H}_{2} \mathrm{O}+\mathrm{NiSO}_{4} \rightarrow 3 \mathrm{NaH}_{2} \mathrm{PO}_{3}+\mathrm{H}_{2} \mathrm{SO}_{4}+2 \mathrm{H}_{2}+\mathrm{Ni} \\
& 2 \mathrm{H}_{2} \mathrm{PO}_{2}^{-}+\mathrm{Ni}^{++}+2 \mathrm{H}_{2} \mathrm{O} \rightarrow 2 \mathrm{H}_{2} \mathrm{PO}_{3}^{-}+\mathrm{H}_{2}+2 \mathrm{H}^{+}+\mathrm{Ni} \\
& \mathrm{Ni}^{++}+\mathrm{H}_{2} \mathrm{PO}_{2}^{-}+\mathrm{H}_{2} \mathrm{O} \rightarrow \mathrm{NiO}+\mathrm{H}_{2} \mathrm{PO}_{3}^{-}+2 \mathrm{H}^{+} \\
& \mathrm{H}_{2} \mathrm{PO}_{2}^{-}+1 \mathrm{H}_{2} \rightarrow \mathrm{H}_{2} \mathrm{O}+\mathrm{OH}^{-}+\mathrm{P}_{2} \\
& 3 \mathrm{H}_{2} \mathrm{PO}_{2}^{-} \rightarrow \mathrm{H}_{2} \mathrm{PO}_{3}^{-}+\mathrm{H}_{2} \mathrm{O}+2 \mathrm{OH}^{-}+2 \mathrm{P}
\end{aligned}
$$


Redox reaction as shown in equation (3) can be further explained in reactions (1) and (2), in which Nickel was converted from Nickel ion to metal. Moreover, reaction (5) further explained reaction 4 which explained the reduction of Phosphorus. The layout for the bath was prepared as shown in Figure 2. Different chemicals added to develop EN-P coating are presented in Table 1. Autcatalytic reaction was followed as shown in Figure 3.

Table 1. EN-P bath with functions $[25,26]$.

\begin{tabular}{lc}
\hline \multicolumn{1}{c}{ Components } & Functions \\
\hline $\begin{array}{l}\text { Nickel Ion source of metal } \\
\text { Complexants stabilises the solution } \\
\text { Buffers control pH (long term) }\end{array}$ & Reducing agent as a source of electrons \\
$\begin{array}{l}\text { Stabiliser prevents solution } \\
\text { breakdown }\end{array}$ & Accelerators activates reducing agent \\
pH regulators
\end{tabular}

The amount as shown in Table 2 was used to prepare the EN-P bath with bath A without Nano additives and bath B with Nano additives [27]. The bath was prepared by adding 6 grams of $\mathrm{NiCl} 2,8$ grams of $\mathrm{H}_{2} \mathrm{NaO}_{2} \mathrm{P} . \mathrm{H}_{2} \mathrm{O}, 10$ grams of $\mathrm{NH}_{4} \mathrm{Cl}$ and 5 grams of $\mathrm{Na}_{3} \mathrm{C}_{6} \mathrm{H}_{5} \mathrm{O}_{7}$ in $200 \mathrm{ml}$ of distilled water against each. Based on the quantity, $50 \mathrm{ml}$ were taken from each beaker and mixed to form $200 \mathrm{ml}$ solution (refer Table 2). $0.5 \%, 1 \%, 1$, $5 \%$ and $2 \%$ of Nano additives were added in the solution and put on a shaker for almost one hour so that the Nano additives were completely dissolved. Later, the solution was put in hot oil bath when the temperature of the bath reached $85{ }^{\circ} \mathrm{C}$ with $\mathrm{pH}$ value of the solution remained at 8 . When temperature reached $85^{\circ} \mathrm{C}$, the substrate was put in a vertical position inside the beaker. Due to the polished surface as well as temperature reaching 85 ${ }^{0} \mathrm{C}$, reaction immediately started [27]. Due to the reaction, $\mathrm{pH}$ value dropped and Ammonia was added to maintain the $\mathrm{pH}$ value.

Table 2. Chemicals used in preparation of EN-P bath [11].

\begin{tabular}{|c|c|c|c|}
\hline Particulars & Bath A (200ml) & Bath B (200ml) & Description \\
\hline Nickel Chloride & $(6 \mathrm{~g} / 200 \mathrm{ml})$ & $6 \mathrm{~g} / 200 \mathrm{ml}$ & Source of $\mathrm{Ni}$ - metal \\
\hline Sodium hypophosphite & $(8 \mathrm{~g} / 200 \mathrm{ml})$ & $8 \mathrm{~g} / 200 \mathrm{ml}$ & $\begin{array}{l}\text { Reducing Agent and } \\
\text { source for Phosphorous } \\
\text { Stops solution }\end{array}$ \\
\hline Sodium tri citrate (stabiliser) & $(5 \mathrm{~g} / 200 \mathrm{ml})$ & $5 \mathrm{~g} / 200 \mathrm{ml}$ & breakdown \\
\hline $\begin{array}{l}\text { Ammonium Chloride } \\
\text { (complexing agent) }\end{array}$ & $(10 \mathrm{~g} / 200 \mathrm{ml})$ & $10 \mathrm{~g} / 200 \mathrm{ml}$ & Stabilises the solution \\
\hline Ammonia Solution & $5 \mathrm{ml}$ & $6 \mathrm{ml}$ & Maintains the $\mathrm{pH}$ value \\
\hline $\begin{array}{l}\text { Palladium Chloride } \\
\text { Nano Copper oxide }<50 \mathrm{~nm} \\
\text { Nano Aluminum oxide }<50 \\
\mathrm{~nm} \\
\text { Nano Zinc oxide }<50 \mathrm{~nm}\end{array}$ & & $\begin{array}{l}0.5 \mathrm{~g} \\
(0.2 \mathrm{~g} / 200 \mathrm{ml})\end{array}$ & $\begin{array}{l}\text { Striking agent (if } \\
\text { required) } \\
4 \text { different Nano additive } \\
\text { concentrations } \\
\text { considered } 0.5,1,1.5 \text { and } \\
2 \% \text {. }\end{array}$ \\
\hline
\end{tabular}

By varying the concentrations of Nano additives from $0.1 \%, 0.5 \%, 1 \%$, and $2 \%$ following the volumetric quantity, Nano additives were added in the bath as shown in Table 3. 
Table 3. Varying concentrations of Nano additives.

\begin{tabular}{ll}
\hline Concentration & Qty of Nano to be added in EN-P bath \\
\hline $0.1 \%$ & $0.2 \mathrm{ml}$ of Nano additive in $200 \mathrm{ml}$ solution \\
& \\
$0.5 \%$ & $1 \mathrm{ml}$ of Nano additive in $200 \mathrm{ml}$ solution \\
$1 \%$ & $2 \mathrm{ml}$ of Nano additive in $200 \mathrm{ml}$ solution \\
$2 \%$ & $4 \mathrm{ml}$ of Nano additive in $200 \mathrm{ml}$ solution \\
\hline
\end{tabular}

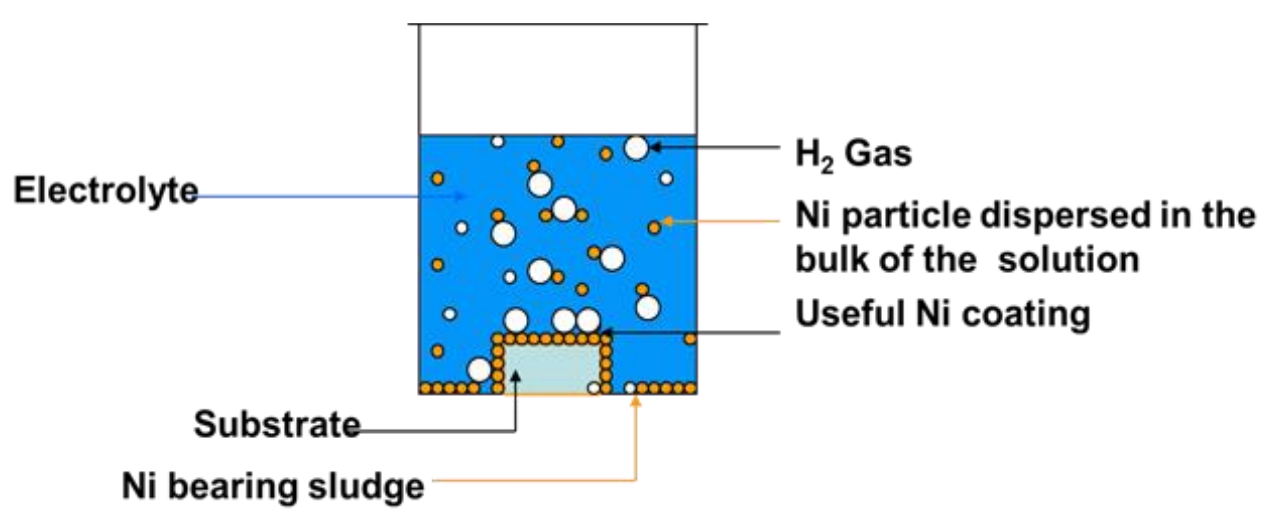

Figure 3. Bath deposition on substrate.

\section{Preparation of Samples}

Samples of size 20x20x7 $\mathrm{mm}^{3}$ from ASTM A106B as substrate used in Oman oil pipelines were prepared to carry out mechanical, chemical, and corrosion resistance evaluation as shown in Figure 3 and to find the best coating performance with different combinations of Nano additives when dipped and coated in EN-P bath. Samples after electroless coating with Nano additives are presented in Figure 4.
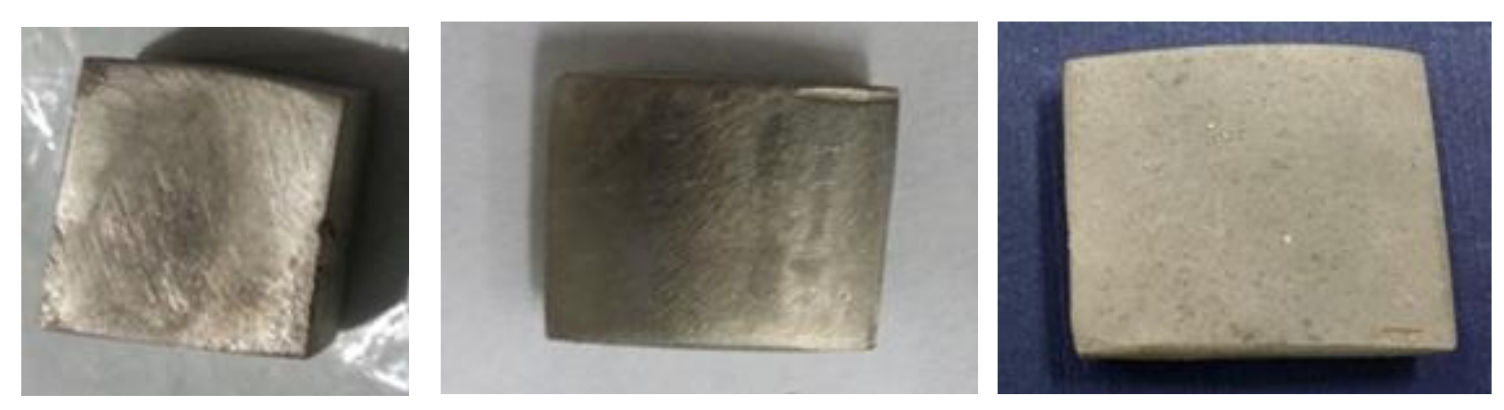

Figure 4. EN-P with Nano $\mathrm{Al}_{2} \mathrm{O}_{3}$; EN-P coating; EN-P coating with Nano CuO.

After preparation of samples, the coating efficiency was calculated based on the percentage of Nickel deposited on the substrate and the rest that was wasted in the electrolyte and elsewhere was considered [28].

In EN-P bath, $\mathrm{NiCl} 2$ is 30 gms / litre

For $200 \mathrm{ml}$ solution $\mathrm{NiCl} 2$ is $6 \mathrm{gms} / 200 \mathrm{ml}$

Therefore in aqueous bath $\mathrm{Nit}=2.71 \mathrm{gms}$

Substrate weight before coating $=37.53 \mathrm{gms}$

Substrate weight after coating $=38.20 \mathrm{gms}$ 
Weight of coating Nip $=38.20-37.53=0.67$ gms.

Coating Efficiency $=\mathbf{N i p} / \mathbf{N i t}=0.67 / 2.71=0.2472=24.72 \%$

$24.72 \%$ of coating efficiency stated that despite of better corrosion resistance properties including surface roughness, wear resistance and micro hardness, the coating efficiency was appreciably reduced $[29,30]$. Due to auto catalytic reaction on the coating surface and due to less surface tension of the electrolyte, around $75 \%$ of the Nickel escaped from the coated surface and may be sticking on the surface of the beaker or on the filter paper. To enhance the coating efficiency and to reduce the escape of Nickel from the bath, addition of surfactants [31], [32] will improve the properties of the coatings

\section{RESULTS AND DISCUSSION}

The coated samples based on ASTMA106 substrate were developed with 0.5, 1, 1.5 and $2 \%$ concentration. These samples were carried out with mechanical, chemical and corrosion resistance evaluation. Results were discussed as under:

\section{Surface Morphology}

The scanning electron microscope (SEM) images with and without Nano additives are presented. SEM image prepared from Bath A (refer Table 2) is shown in Figure 5 below. Without Nano additives, the surface of the coating had lower amount of Nickel particles. Moreover, the matrix of the coated surface had less deposit of Nickel and the rest was wasted in the electrolyte. Due to less and non-uniform deposition of Nickel, formation of higher surface roughness was evident [14]. With the addition of Nano additives, the surface morphology was changed from non-smooth nodular appearance to a smooth surface resulting in lower surface finish values. The reason was that the amount of Nickel particles deposited on the substrate surface was enhanced due to the fact that the surfactant reduced the contact angle, indicating better wettability of $\mathrm{Ni}-\mathrm{P}$ deposit on the substrate (refer Table 4).

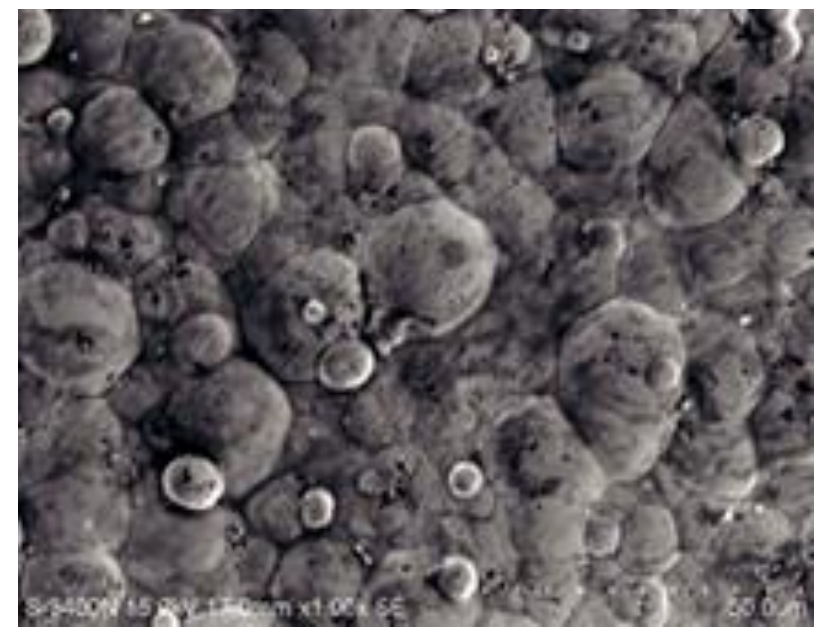

Figure 5. EN-P bath A without Nano additives.

\section{Surface Roughness}

On the EN-coated substrate surface, the traces of Nano- $\mathrm{Al}_{2} \mathrm{O}_{3}$, Nano-CuO and Nano$\mathrm{ZnO}$ particles are clearly seen over the $\mathrm{Ni}-\mathrm{P}$ matrix and the existence of Nano-additives was confirmed with EDX (refer Figure 16-18). Among the three Nano additives, the best 
value was reported at $1 \%$ concentration in the EN-P bath. Addition of Nano- $\mathrm{Al}_{2} \mathrm{O}_{3}$ resulted in smooth surface finish in the order of $2.12 \mu \mathrm{m}$ as compared to Nano-CuO $(2.2$ $\mu \mathrm{m})$ and Nano-ZnO $(2.3 \mu \mathrm{m})$. The values are presented in Table 4. One of the main advantages of electroless coating as compared to electroplated coating is it provides uniform deposition on the substrate surface following the surface contour. Moreover, EN$\mathrm{P}$ plating does not have electric source DC to form the reaction as it has been done in electroplating the reaction in EN-P coating based on three major steps which are temperature of the bath between 80 to $90{ }^{\circ} \mathrm{C}, \mathrm{pH}$ value 8 to 9 and the substrate properly polished. Quality of the coating is dependent on the substrate surface and its metallurgical conditions. The same is shown in SEM images at various Nano additive concentrations of Nano $\mathrm{Al}_{2} \mathrm{O}_{3}$ as shown in Figure 6. Poor surface finish causes porosity and poor coating quality [28]. Surface roughness of the substrate after different types of coatings is shown in Figure 10. It is evident that after $1 \%$ concentration, further increase of concentration of Nano additives did not improve the quality of the surface [7]. The same can be further proven by the deposition of agglomeration of Nano particles over the EN-P matrix that led to increased surface roughness [14]. Referring to Figure 7, the values of Nano additives at $1 \%$ concentration and the values above almost became constant and the variation was almost negligible. The result indicated at high concentration value, surface roughness variation was reduced to constant.

Table 4. Surface roughness of coatings at various concentrations of Nano additives.

\begin{tabular}{clcccc}
\hline S/No & \multicolumn{1}{c}{ Type of coating } & \multicolumn{4}{c}{$\begin{array}{c}\text { Surface Roughness Rz } \mu \mathrm{m} \\
\text { at different Nano additive conc. }\end{array}$} \\
\cline { 3 - 6 } & & $0.1 \%$ & $0.5 \%$ & $1 \%$ & $2 \%$ \\
\hline 1 & EN-P with Nano $\mathrm{ZnO}$ & 2.76 & 2.14 & 2.3 & 2.4 \\
2 & EN-P with Nano $\mathrm{Al}_{2} \mathrm{O}_{3}$ & 3.54 & 2.66 & 2.12 & 2.23 \\
3 & ENP with Nano $\mathrm{CuO}$ & 3.76 & 2.375 & 2.2 & 2.12 \\
4 & EN-P without Nano additive & \multicolumn{4}{c}{2.13} \\
\hline
\end{tabular}

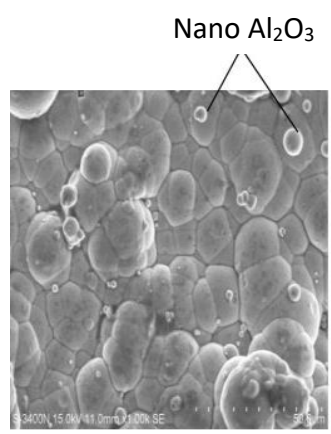

(a)

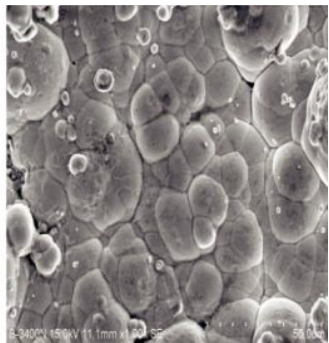

(b)

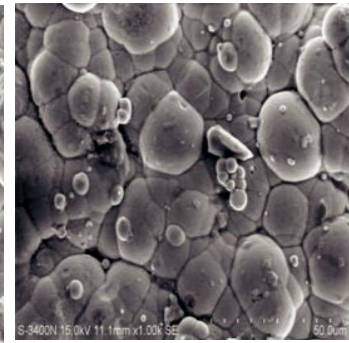

(c)

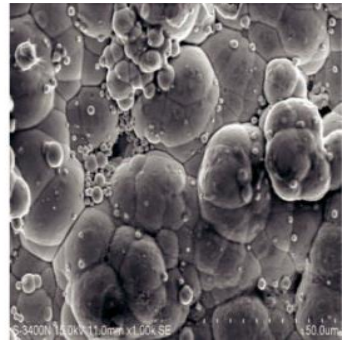

(d)

Figure 6. SEM micrograph (1000x) of EN-P coated with various $\mathrm{Al}_{2} \mathrm{O}_{3}$ concentrations: (a) $0.1 \%$, (b) $0.5 \%$, (c) $1 \%$, and (d) $2 \%$.

\section{Micro Hardness}

Buehler Vickers Micro hardness Tester (Micromet II) with a diamond indenter was used to measure the micro hardness of the coatings. The indenter load was taken as 25 to 100 grams based on the coating thickness. The depth of indentation was kept below $1 / 5$ th of the coating thickness so that mechanical properties of the substrate substrate would not be changed. Figure 8 shows the variation of micro hardness of EN-P coating with respect 
to $\mathrm{Nano} \mathrm{Al}_{2} \mathrm{O}_{3}, \mathrm{CuO}$, and $\mathrm{ZnO}$ at different concentrations. At low percentages of Nano additives, the micro hardness value was low; when there was increase in the percentages of Nano additives, the micro hardness value was high and the maximum at $1 \%$ addition of Nano additives as presented in Table 5. The Nano additives of $\mathrm{Al}_{2} \mathrm{O}_{3}$ showed high hardness (595 VHN200) at $1 \%$ followed by $\mathrm{CuO}$ (573 VHN200) and $\mathrm{ZnO}$ (560 VHN200). The improvement in micro hardness values of EN-P coatings with Nano additives may be due to the uniform deposition of Nanoparticles on the Ni-P matrix and filling the micro gaps of Ni-P coated layer, thus increasing its density [29]. Referring to Figure 8 , micro hardness after $1 \%$ concentration reported a constant incremental variation and at around $2 \%$ concentration, the hardness remained constant. Very few cracks were

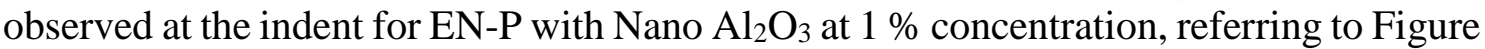
9. To have a fair comparison at $1 \%$ concentration, EN-P with $\mathrm{Nano} \mathrm{CuO}$ and $\mathrm{ZnO}$ are also shown in Figures 10 and 11.

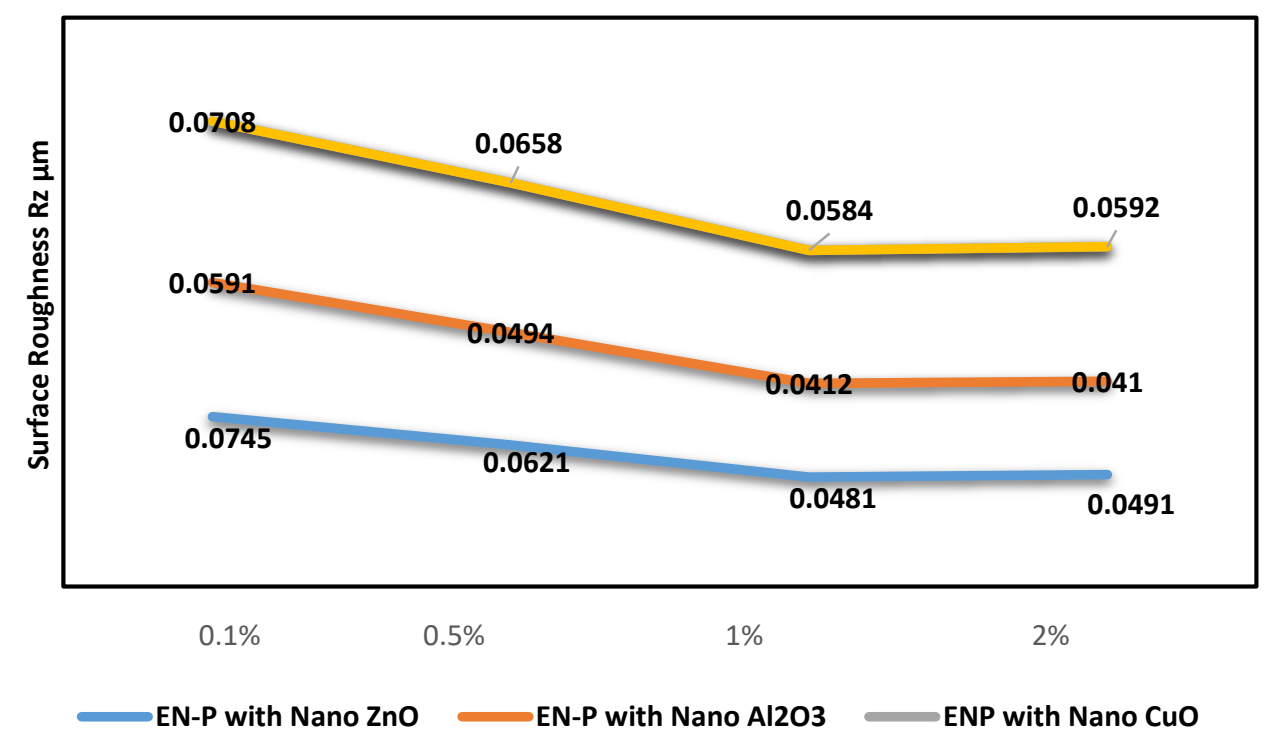

Figure 7. Surface roughness of Nano additives.

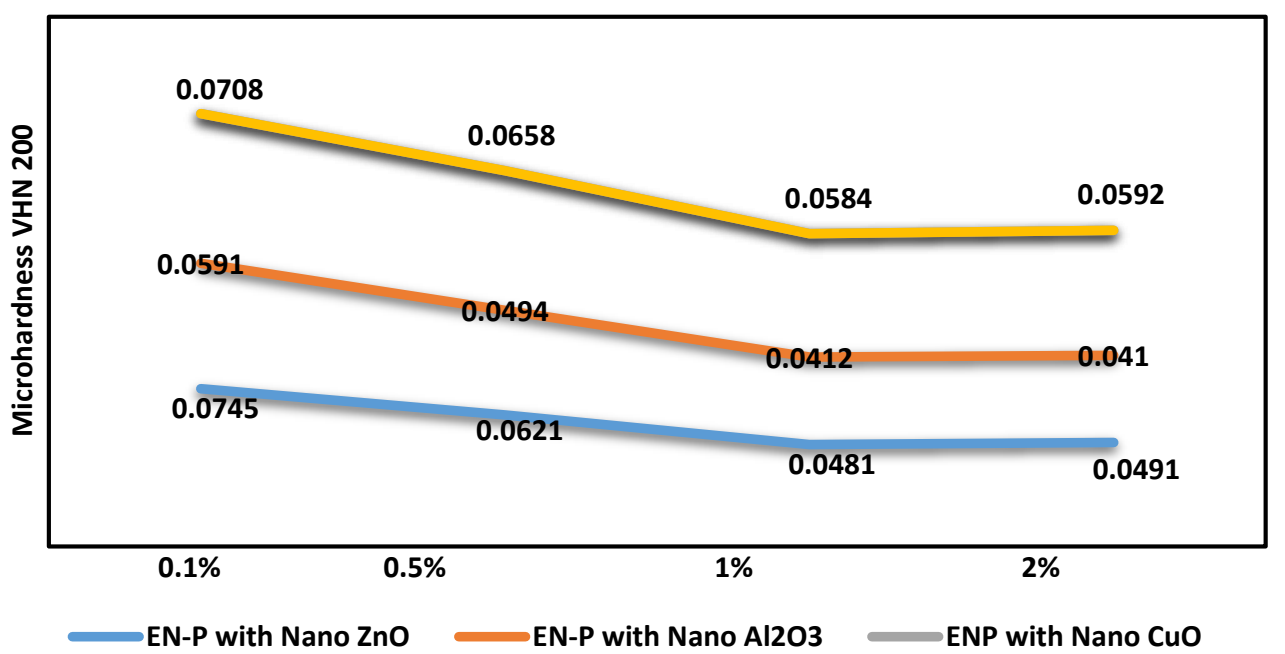

Figure 8. Micro hardness of Nano additives. 
Table 5. Micro hardness of EN-P coated samples with Nano additives

\begin{tabular}{|c|c|c|c|c|c|}
\hline \multirow[t]{2}{*}{ S/No } & \multirow[t]{2}{*}{ Type of coating } & \multicolumn{4}{|c|}{$\begin{array}{l}\text { Vicker Hardness VHN200 } \\
\text { at different Nano additive } \\
\text { concentrations }\end{array}$} \\
\hline & & $0.1 \%$ & $0.5 \%$ & $1 \%$ & $2 \%$ \\
\hline 1 & EN-P with Nano ZnO & 548 & 553 & 560 & 566 \\
\hline 2 & EN-P with Nano $\mathrm{Al}_{2} \mathrm{O}_{3}$ & 574 & 582 & 595 & 598 \\
\hline 3 & ENP with Nano $\mathrm{CuO}$ & 559 & 566 & 573 & 577 \\
\hline 4 & EN-P without Nano additives & \multicolumn{4}{|c|}{450} \\
\hline
\end{tabular}

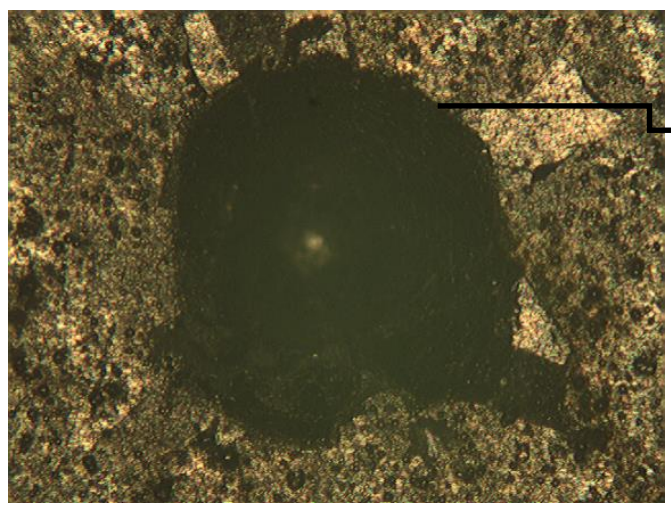

$50 X$

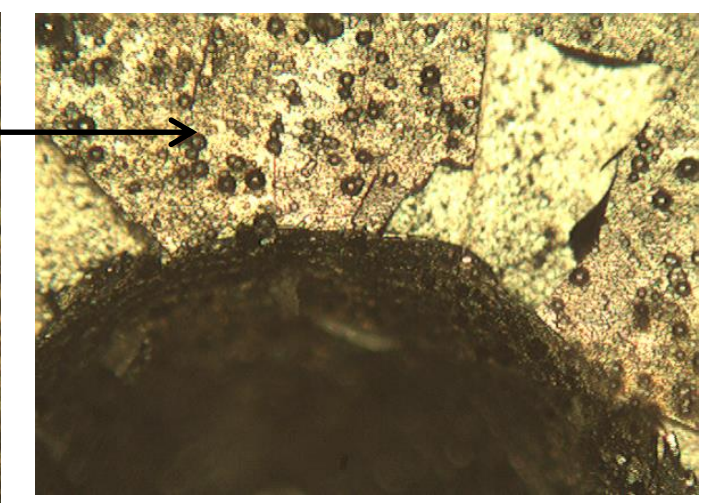

$100 X$

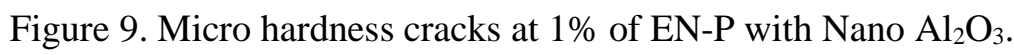

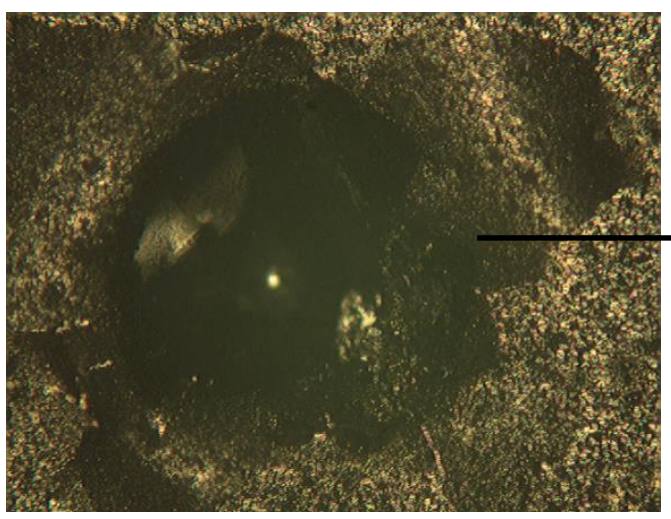

$50 \times$

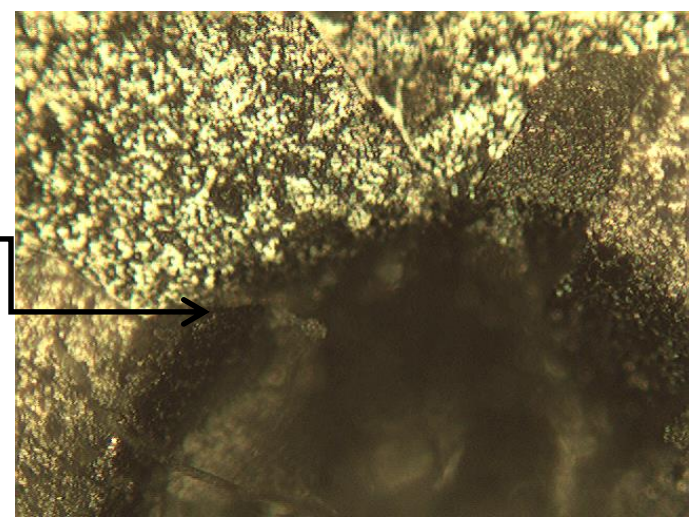

100X

Figure 10. Micro hardness cracks at $1 \%$ of EN-P with Nano $\mathrm{CuO}$.

\section{Specific Wear Rate}

Wear morphology of coated samples at different percentages of Nano additives for Nano $\mathrm{Al}_{2} \mathrm{O}_{3}$ and Nano $\mathrm{CuO}$ is presented in Figure 15. It is evident that at lower concentrations $(0.5 \%)$ of Nano additives, the delamination of coatings and their debris are clearly visible. As the percentage of Nano additives increased, the wear tracks are smooth and demonstrated a low wear rate. The other reason for the low wear rate at higher concentration of Nano additives was increased hardness of coatings. At $1 \%$ concentration, the surface texture seemed to be smooth as compared to other variations 
[33]. The graphical presentations for specific wear rate of EN-P coatings for various Nano additives of $\mathrm{Al}_{2} \mathrm{O}_{3}, \mathrm{CuO}$ and $\mathrm{ZnO}$ are shown in Figures 12 to 14. It is reported that with increased percentage of Nano additives, the EN-coatings showed better wear resistance. The greater the hardness, the fewer the deformation and consequently, there was less intimate contact, leading to lower friction. The corresponding graphical values are shown in Table 6. It is evident that the minimum specific wear rate was reported at $1 \%$ concentration; above it, the value almost remained constant.

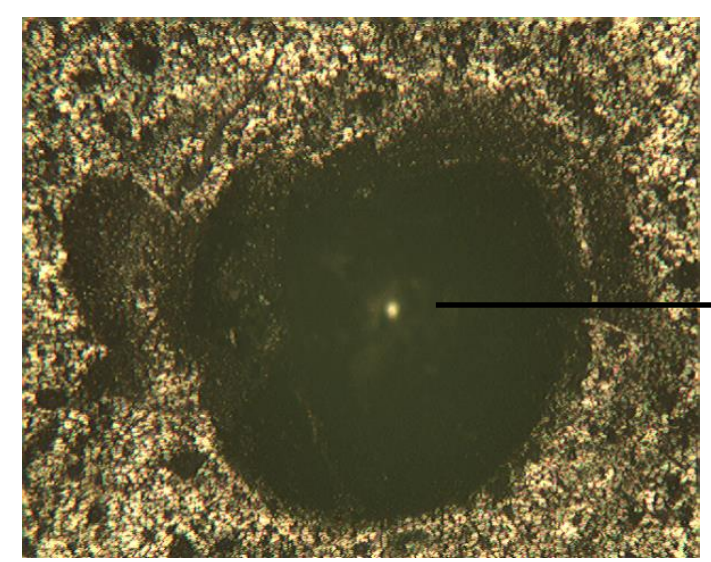

$50 \mathrm{X}$

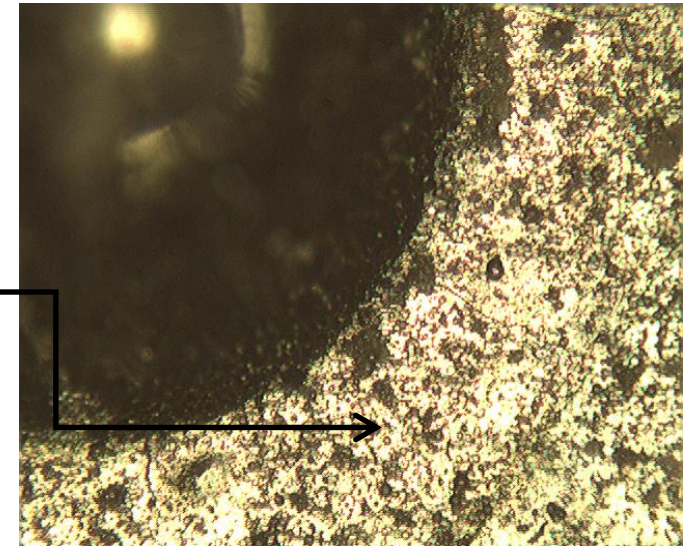

100X

Figure 11. Micro hardness cracks at 1\% of EN-P with Nano ZnO.

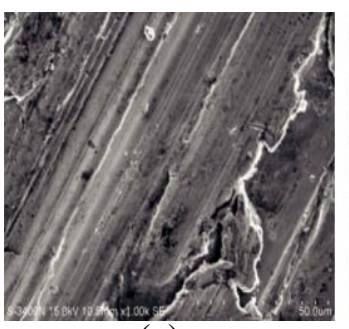

(a)

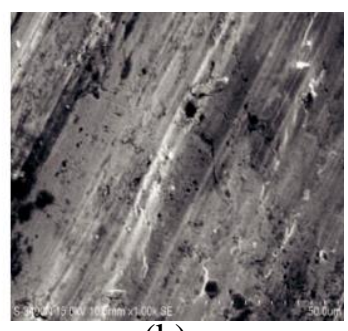

(b)

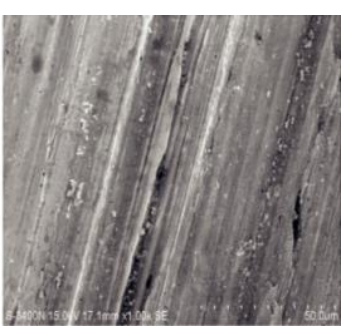

(c)

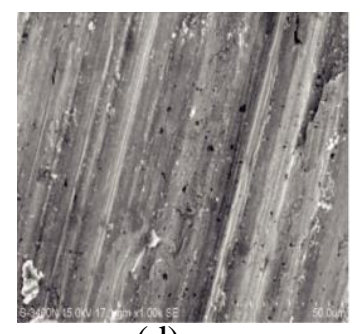

(d)

Figure 12. SEM micrograph (1000x) of wear track for various $\mathrm{Al}_{2} \mathrm{O}_{3}$ for (a) $0.1 \%$, (b) $0.5 \%$, (c) $1 \%$ and (d) $2 \%$.

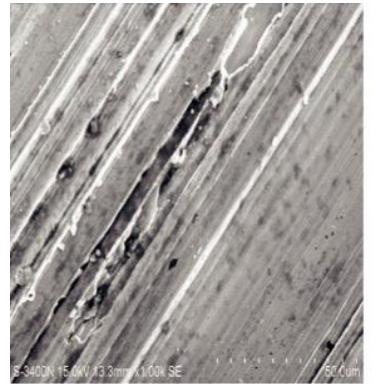

(a)

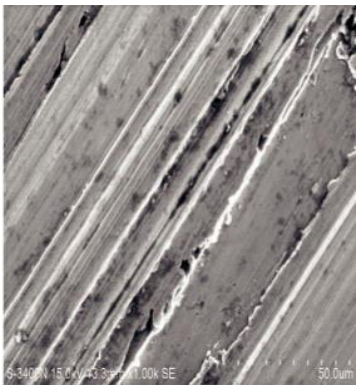

(b)

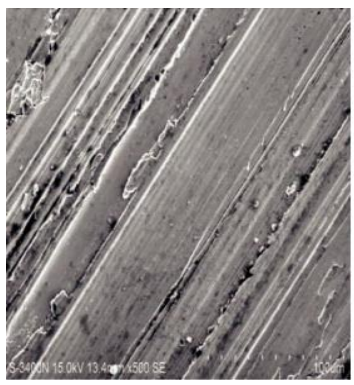

(c)

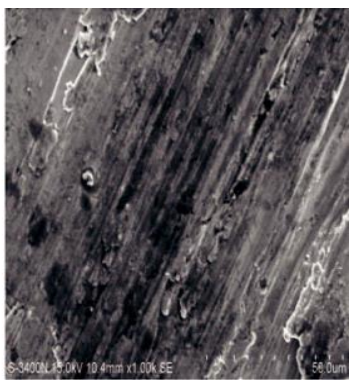

(d)

Figure 13: SEM micrograph (1000×) of wear track for various $\mathrm{CuO}$ for (a) $0.1 \%$, (b) $0.5 \%$, (c) $1 \%$ and (d) $2 \%$ 


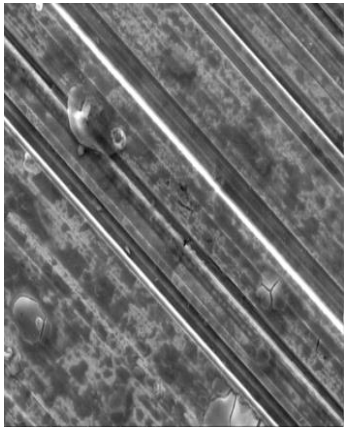

(a)

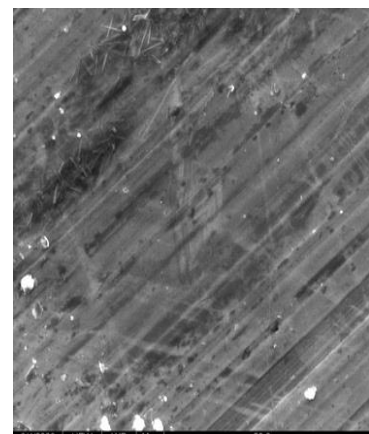

(b)

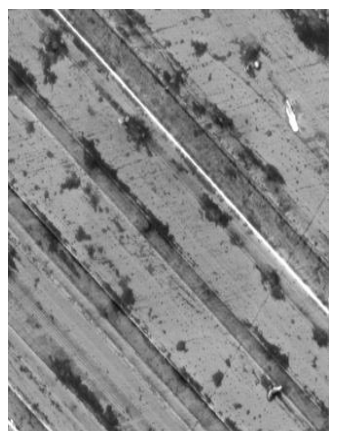

(c)

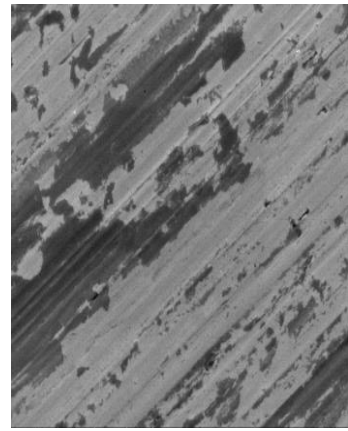

(d)

Figure 14: SEM micrograph (1000x) of wear track for various $\mathrm{ZnO}$ for (a) $0.1 \%$, (b) $0.5 \%$, (c) $1 \%$ and (d) $2 \%$

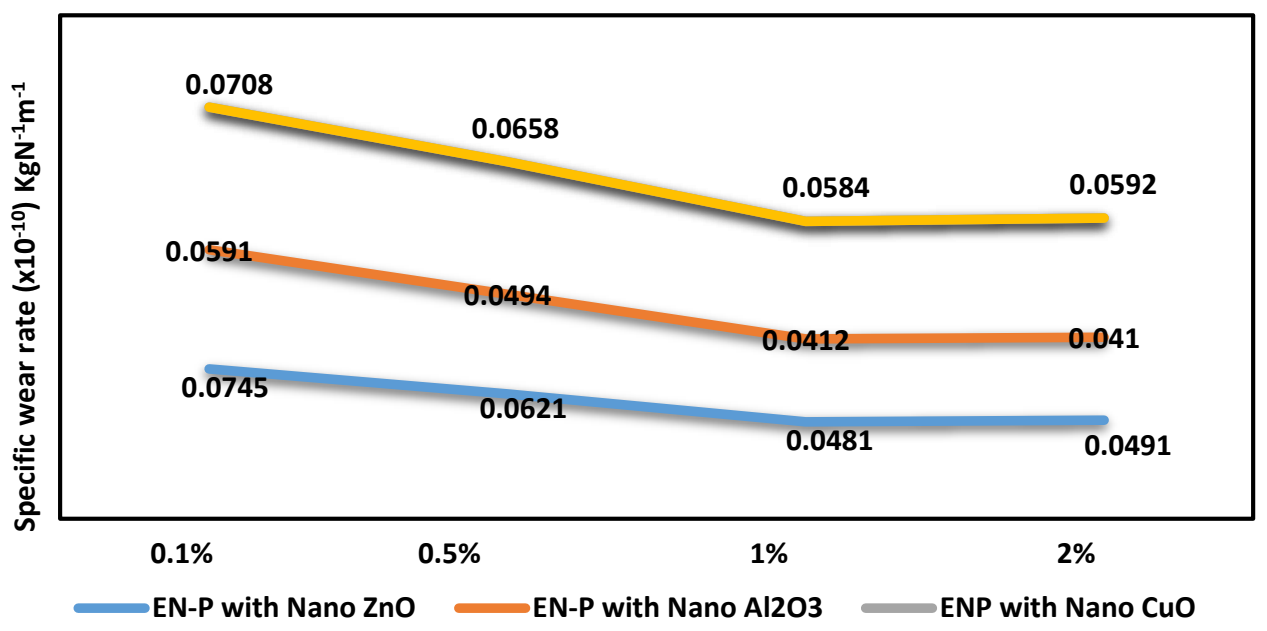

Figure 15: Specific wear rate of Nano additives

Table 6. Specific wear rate of EN-P coated samples with Nano additives.

\begin{tabular}{llcccc}
\hline & & \multicolumn{4}{c}{$\begin{array}{c}\text { Specific wear rate at different } \\
\text { Nano additive concentrations } \\
\left(\times 10^{-10}\right)\end{array}$} \\
\cline { 3 - 6 } & & \multicolumn{4}{c}{$\mathrm{KgN}^{-1} \mathrm{~m}^{-1}$} \\
\hline 1 & EN-P with $\mathrm{Nano} \mathrm{ZnO}$ & 4.65 & 3.7 & 2.58 & 2.49 \\
2 & EN-P with $\mathrm{Nano} \mathrm{Al}_{2} \mathrm{O}_{3}$ & 2.83 & 2.23 & 1.57 & 1.51 \\
3 & ENP with Nano $\mathrm{CuO}$ & 3.88 & 3.09 & 2.15 & 2.08 \\
\hline
\end{tabular}

\section{X- Ray Diffraction}

Presence of elements in the coated samples was investigated at different Nano additive concentrations. Figures 16 to 18 represent the elements at $1 \%$ concentration for Nano $\mathrm{Al}_{2} \mathrm{O}_{3}, \mathrm{CuO}$ and $\mathrm{ZnO}$. The presence of $\mathrm{Ni}$ reflected the strength of the coating and Phosphorous showed the resistance against corrosion [22].

\section{Corrosion Resistance}

EN-P coated samples of size $20 \times 20 \times 7 \mathrm{~mm}^{3}$ with Nano additives at different varying concentrations were conducted by performing atmospheric exposure test (conducted for 
60 days) as shown in Table 7 and Figure 19 for Potentio-static corrosion test, Table 8 and Figure 20 for dry/wet test (conducted for 14 days), and Table 9 and Figure 21 to identify the average corrosion rate. The corrosion rate against atmospheric exposure test and dry/wet test was based on weight loss [34] and Potentio-static corrosion test was based on potentio difference [35]. The tests were conducted at the ambient conditions of Oman where temperature varies from 25 to $52{ }^{\circ} \mathrm{C}$ with an average wind speed of 3 to $5 \mathrm{~m} / \mathrm{s}$ and humidity ranges from 55 to $65 \%$. It is reported that among all the variations of Nano additives in EN-P coated samples based on the three corrosion resistance test, $1 \%$ concentration presented the best corrosion resistance rate [27].
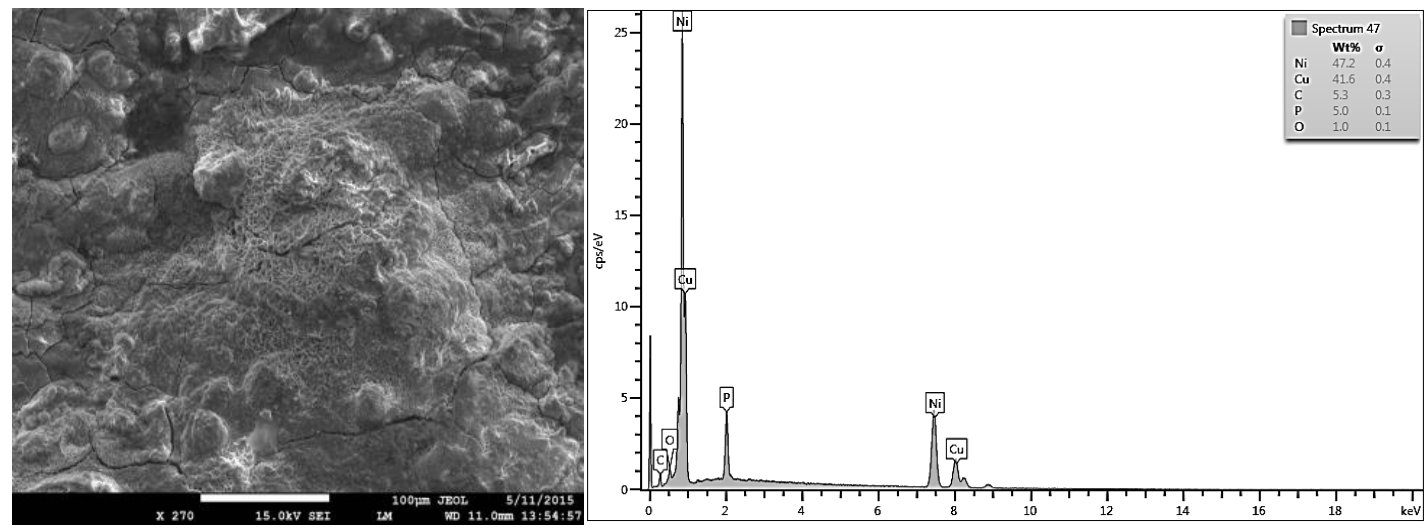

Figure 16. EN-P with $\mathrm{Nano} \mathrm{CuO}$ at $1 \%$ concentration.
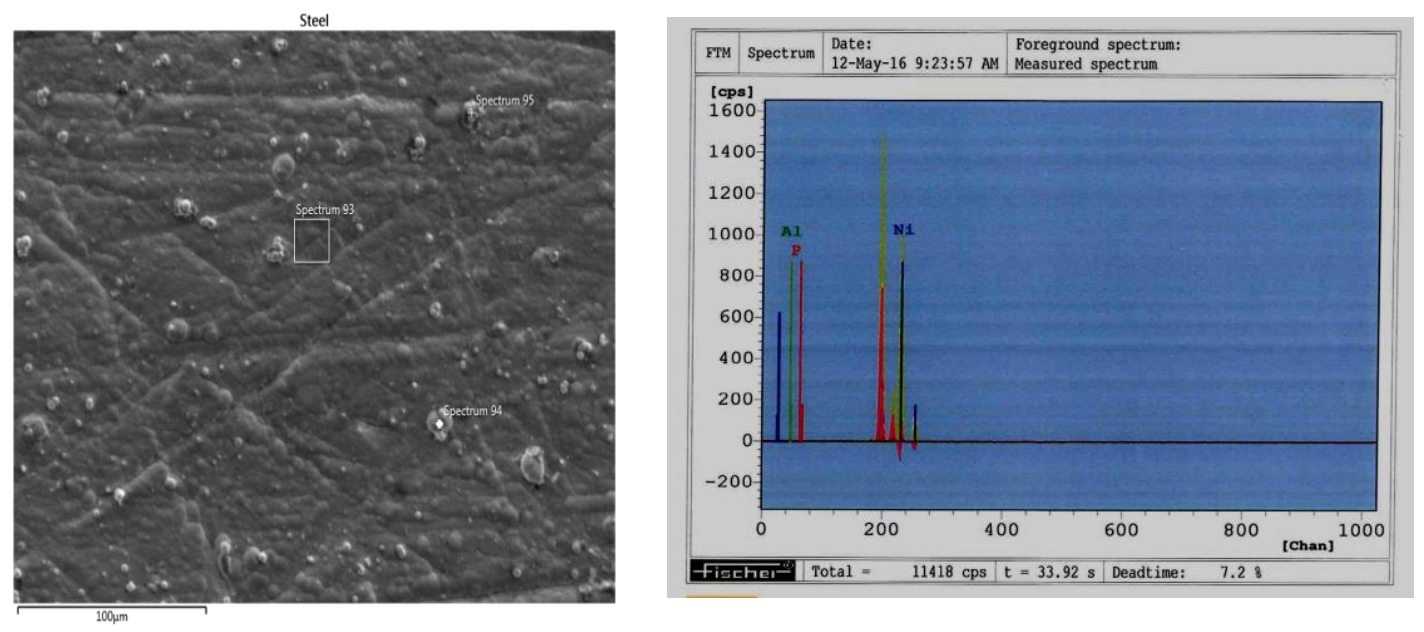

Figure 17. EN-P with $\mathrm{Nano} \mathrm{Al}_{2} \mathrm{O}_{3}$ at $1 \%$ concentration.

Table 7. Atmospheric exposure test for varying concentrations [36].

\begin{tabular}{|c|c|c|c|c|}
\hline \multirow[t]{2}{*}{ S/No } & \multirow[t]{2}{*}{ Type of coating } & \multicolumn{3}{|c|}{$\begin{array}{l}\text { Atmospheric exposure test in } \\
\text { millimeter per year } \\
\text { (mmpy) }\end{array}$} \\
\hline & & $0.1 \%$ & $0.5 \%$ & $2 \%$ \\
\hline 1 & EN-P with Nano ZnO & 0.0633 & 0.05680 .0412 & 0.0446 \\
\hline 2 & EN-P with Nano $\mathrm{Al}_{2} \mathrm{O}_{3}$ & 0.0412 & 0.03740 .0353 & 0.035 \\
\hline 3 & ENP with Nano $\mathrm{CuO}$ & 0.0527 & 0.05120 .0471 & 0.0468 \\
\hline 4 & EN-P without Nano additive & & 0.0843 & \\
\hline
\end{tabular}



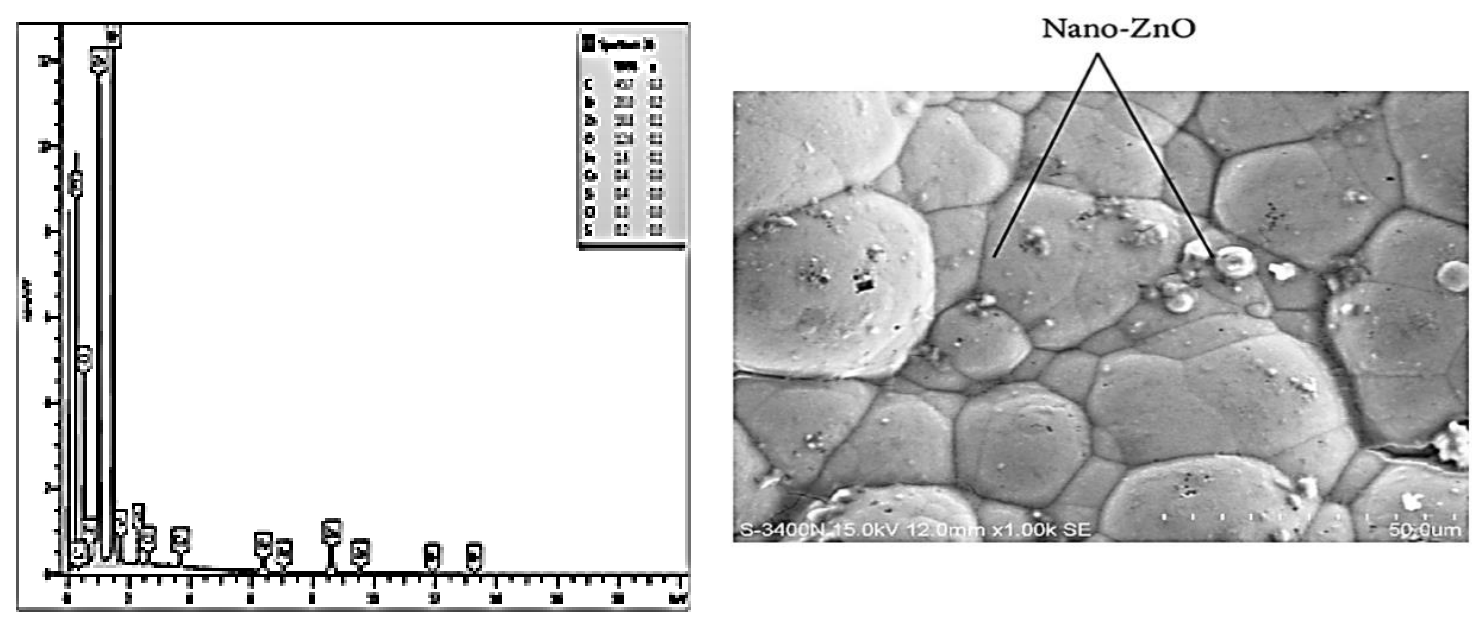

Figure 18. EN-P with Nano $\mathrm{ZnO}$ at $1 \%$ concentration.

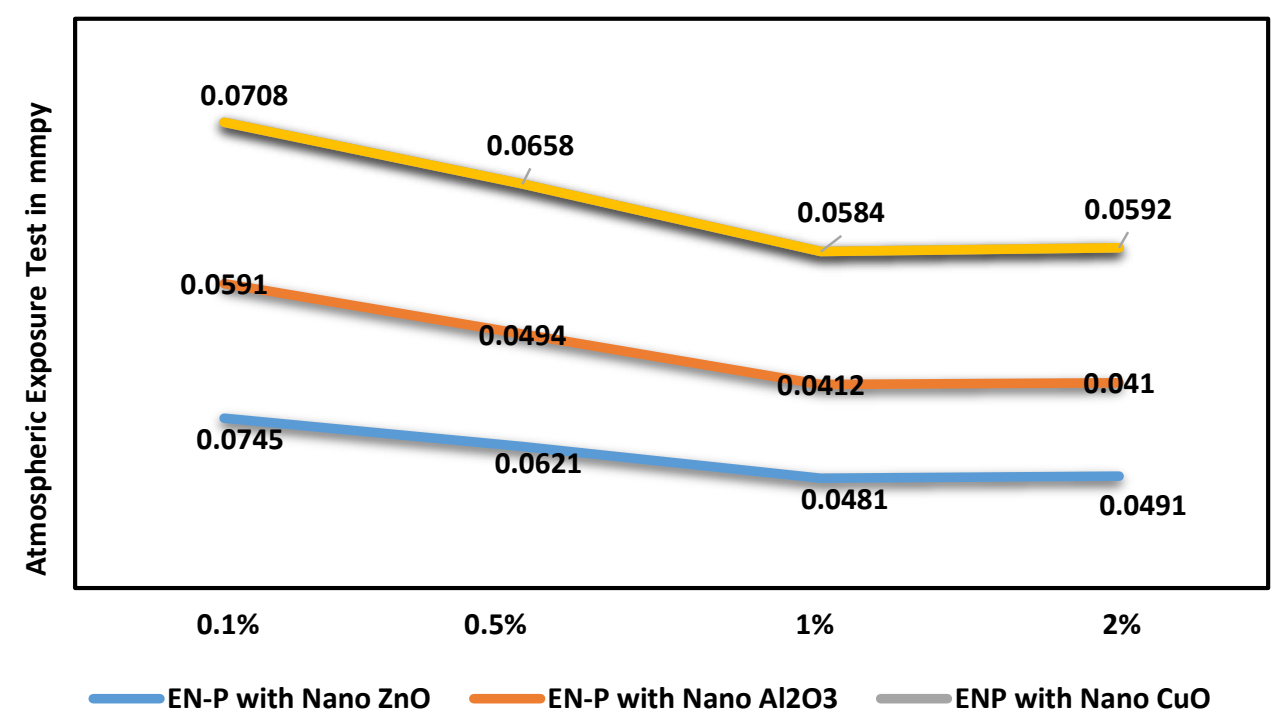

Figure 19: Graphical presentation for EN-P with Nano additives

Table 8. Potentio-Static corrosion test for varying concentrations.

\begin{tabular}{llllll}
\hline \multirow{2}{*}{ S/No } & \multicolumn{1}{c}{ Type of coating } & \multicolumn{4}{c}{$\begin{array}{c}\text { Potentio-Stat corrosion test in } \\
\text { millimeter per year } \\
(\text { mmpy) }\end{array}$} \\
\cline { 3 - 6 } & & $0.1 \%$ & $0.5 \%$ & $1 \%$ & $2 \%$ \\
\hline 1 & EN-P with Nano $\mathrm{ZnO}$ & 0.1013 & 0.1002 & 0.0834 & 0.0839 \\
2 & EN-P with Nano $\mathrm{Al}_{2} \mathrm{O}_{3}$ & 0.0942 & 0.0861 & 0.0718 & 0.0716 \\
3 & ENP with Nano $\mathrm{CuO}$ & 0.0995 & 0.0948 & 0.0754 & 0.0744 \\
4 & EN-P without Nano additive & \multicolumn{4}{c}{0.0742} \\
\hline
\end{tabular}


Table 9. Dry/wet test for varying concentrations.

\begin{tabular}{llcccc}
\hline \multirow{2}{*}{ S/No } & \multirow{2}{*}{ Type of coating } & \multicolumn{4}{c}{ Dry/wet test in millimeter per } \\
\cline { 3 - 6 } & & $0.1 \%$ & $0.5 \%$ & $1 \%$ & $2 \%$ \\
\hline 1 & EN-P with Nano ZnO & 0.0745 & 0.0621 & 0.0481 & 0.0491 \\
2 & EN-P with Nano Al2O3 & 0.0591 & 0.0494 & 0.0412 & 0.0410 \\
3 & ENP with Nano CuO & 0.0708 & 0.0658 & 0.0584 & 0.0592 \\
4 & EN-P without Nano additive & & \multicolumn{3}{c}{1.047} \\
\hline
\end{tabular}

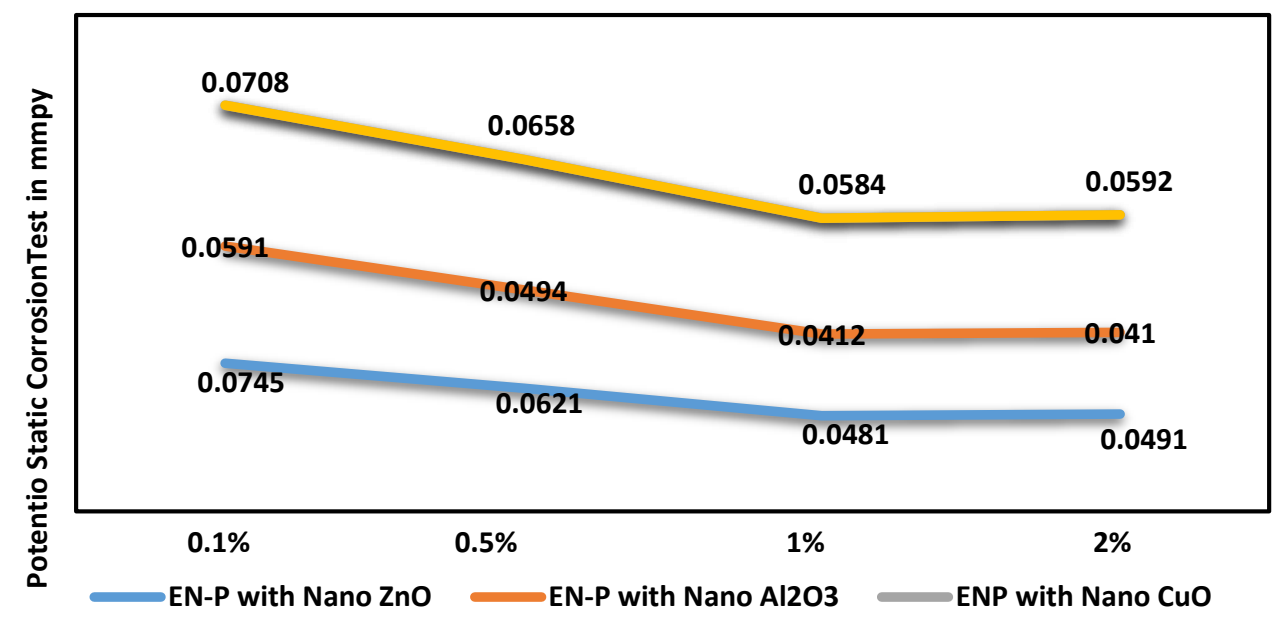

Figure 20. Graphical presentation for EN-P with Nano additives [37].

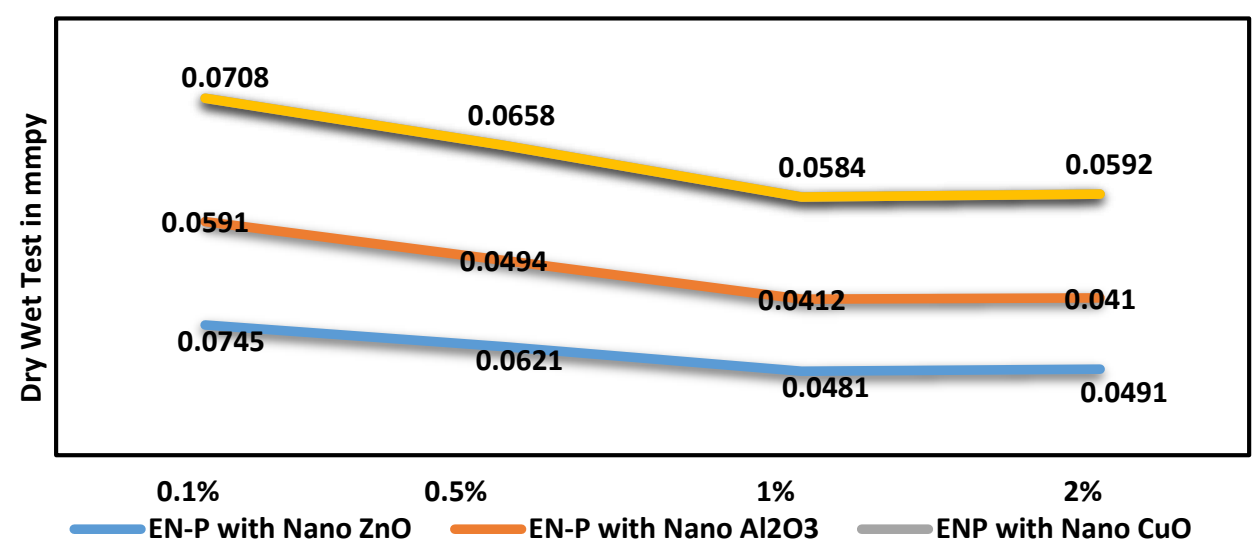

Figure 21. Graphical presentation for EN-P with Nano additives [38].

\section{CONCLUSIONS}

An experimental study under varying coating conditions on the influence of addition of various concentrations of Nano additives in EN-P bath has been done. Based on the results, the best concentration impact of Nano additives by performing different evaluations was identified. Mechanical and chemical properties had been conducted and 
the results were investigated and presented. Based on the present research, the following specific conclusions were drawn:

i) EN-P with Nano additives were coated on ASTM A106B low alloy steel substrate. These samples were examined under mechanical, characterisation and corrosion resistance evaluations. Referring to the comparative performance of the coatings, it is reported that $1 \%$ concentration of Nano additives in EN-P bath gave better performance results compared to other concentrations. EN-P with Nano $\mathrm{Al}_{2} \mathrm{O}_{3}$ reported significant results compared to Nano $\mathrm{CuO}$ followed by Nano $\mathrm{ZnO}$.

ii) Influence of Nano additives under various concentrations in EN-P bath improved

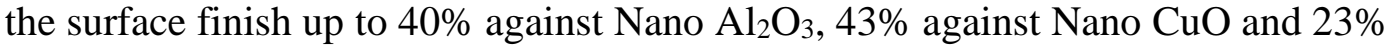
against Nano $\mathrm{ZnO}$. The addition of Nano additives in EN bath avoided the floatation of Nickel particles produced during the coating process resulted in developing a fine layer of Nickel particles deposited on the coated surface.

iii) The addition of Nano additives in the EN-P bath also significantly increased the micro hardness of the coatings due to the addition of Nano additives such as Nano $\mathrm{Al}_{2} \mathrm{O}_{3}$ up to $24 \%$, Nano $\mathrm{CuO}$ up to $21 \%$ and Nano $\mathrm{ZnO}$ up to $20 \%$, respectively. The VHN 200 for EN-P with addition of Nano $\mathrm{Al}_{2} \mathrm{O}_{3}$ was maximum as compared to other Nano additives. The micro hardness value of EN-P coating with Nano additives was improved which may be due to the uniform deposition of Nanoparticles on the Ni-P matrix and filling the micro gaps of Ni-P coated layer.

iv) The EN-P coatings produced with the addition of Nano additives within the EN bath with varying concentrations improved the wear resistance as well. The best result was reported at $1 \%$ concentration for $\mathrm{Nano} \mathrm{Al}_{2} \mathrm{O}_{3}$ up to $27 \%$ and $23.64 \%$ when compared to the coatings produced with Nano $\mathrm{CuO}$ and Nano ZnO. This improvement may be due to the increase in the hardness and the amorphous fraction in the coating.

v) Three types of corrosion resistance test were conducted. At $1 \%$ concentration, the

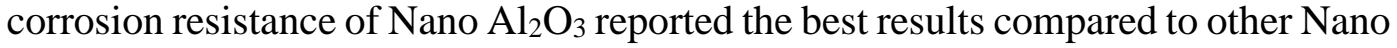
additives. There was an improvement of around 58.12\% of corrosion resistance for EN-P with Nano $\mathrm{Al}_{2} \mathrm{O}_{3}$ compared to EN-P without Nano additive coated samples.

vi) The coating efficiency was reduced to $24.75 \%$ only for EN-P coated samples with Nano additives, meaning that $75.28 \%$ Nickel was wasted in electrolyte. To improve the coating efficiency, surfactants can be added.

\section{ACKNOWLEDGEMENTS}

The authors first of all are obliged to Glasgow Caledonian University U.K. in providing technical advice while formulating the results. Moreover, authors are grateful to Sultan Qaboos University Oman and Indian Institute of technology Madras, India in providing the technical assistance and lab facilities in conducting the experimental work.

\section{REFERENCES}

[1] Singh BP, Jena BK, Bhattacharjee S, Besra L. Development of oxidation and corrosion resistance hydrophobic graphene oxide-polymer composite coating on copper. Surface and Coatings Technology. 2013;232:475-81.

[2] Sudagar J, Lian J, Sha W. Electroless nickel, alloy, composite and nano coatings A critical review. Journal of Alloys and Compounds2013. p. 183-204. 
[3] Mirza M. Surface Coatings on Steel Pipes Used in Oil and Gas Industries - A Review. American Chemical Science Journal. 2016;13.

[4] A. Wurtz A. Etudes sur l'Albumine et sur la Fibrine. 1844.

[5] Popoola L, Grema A, Latinwo G, Gutti B, Balogun A. Corrosion problems during oil and gas production and its mitigation. International Journal of Industrial Chemistry. 2013;4:35.

[6] Patscheider J, Zehnder T, Diserens M. Structure-performance relations in nanocomposite coatings. Surface and Coatings Technology. 2001;146-147:201-8.

[7] Koli DK, Agnihotri G, Purohit R. A Review on Properties, Behaviour and Processing Methods for Al- Nano Al2O3 Composites. Procedia Materials Science. 2014;6:567-89.

[8] Krishnan K, John S, Srinivasan K, Praveen J, Ganesan M, Kavimani P. An overall aspect of electroless Ni-P depositions-A review article. Metallurgical and Materials Transactions A. 2006;37:1917-26.

[9] Jappes JTW, Ramamoorthy B, Nair PK. A study on the influence of process parameters on efficiency and crystallinity of electroless Ni-P deposits. Journal of Materials Processing Technology. 2005;169:308-13.

[10] Apachitei I. Synthesis and characterisation of autocatalytic nickel composite coatings on aluminium: TU Delft, Delft University of Technology; 2001.

[11] Mandich NV, Krulik GA. The evolution of a process: Fifty years of electroless nickel. Metal finishing. 1992;90:25-7.

[12] Barker BD. Electroless deposition of metals. Surface Technology. 1981;12:77-88.

[13] Mirza M. Influence of nano additives on protective coatings for oil pipelines of Oman. International Journal of Chemical Engineering and Applications. 2016;7:221-5.

[14] Dhinakaran R, Elansezhian R, Lalitha AA. Effect of Nanoadditives with Surfactant on the Surface Characteristics of Electroless Nickel Coating on Magnesium-Based Composites Reinforced with MWCNT. Advances in Tribology. 2013;2013:1-10.

[15] Sudagar J, Lian JS, Jiang Q, Jiang ZH, Li GY, Elansezhian R. The performance of surfactant on the surface characteristics of electroless nickel coating on magnesium alloy. Progress in Organic Coatings2012. p. 788-93.

[16] Moniruzzaman M, Roy S. Effect of $\mathrm{pH}$ on electroless Ni-P coating of conductive and non-conductive materials. International Journal of Automotive and Mechanical Engineering. 2011;4:481-9.

[17] Ravisankar B, Tara Chand V. Influence of nanoparticle volume fraction, particle size and temperature on thermal conductivity and viscosity of nanofluids- a review. International Journal of Automotive and Mechanical Engineering. 2013;8:1316-38.

[18] Sahid NSM, Rahman MM, Kadirgama K, Ramasamy D, Maleque MA, Noor MM. Experimental investigation on the performance of the $\mathrm{TiO}_{2}$ and $\mathrm{ZnO}$ hybrid nanocoolant in ethylene glycol mixture towards AA6061-T6 machining. International Journal of Automotive and Mechanical Engineering. 2017;14:391326.

[19] Hussein AM, Bakar RA, Kadirgama K, Sharma KV. Experimental measurements of nanofluids thermal properties. International Journal of Automotive and Mechanical Engineering. 2013;7:850-63.

[20] Asmara YP, Siregar JP, Shah LH, Tezara C. Experimental investigations on corrosion model of welded 6061 aluminum exposed in $\mathrm{NaCl}$ solution. International Journal of Automotive and Mechanical Engineering. 2015;11:2600-7. 
[21] Mirza M. Influence of nano additives on protection of oil pipelines of Oman. IJCEA. 2016;7:221-5.

[22] Kundu S, Das SK, Sahoo P. Properties of electroless Nickel at elevated temperature - A review. Procedia Engineering2014. p. 1698-706.

[23] Vijayanand M, Elansezhian R. Influence of Surfactants on the properties of electroless nickel boron (thallium and lead-free) coatings. Proceedings of the Institution of Mechanical Engineers, Part E: Journal of Process Mechanical Engineering. 2016.

[24] Taheri R. Evaluation of Electroless Nickel-Phosphorus ( EN ) Coatings. PhD Thesis2003. p. 229.

[25] Oh TH, Kwon S. Effect of bath composition on properties of electroless deposited $\mathrm{Co}-\mathrm{P} / \mathrm{Ni}$ foam catalyst for hydrolysis of sodium borohydride solution. International Journal of Hydrogen Energy. 2012;37:17027-39.

[26] Rabizadeh T, Allahkaram SR. Corrosion resistance enhancement of Ni-P electroless coatings by incorporation of nano-SiO2 particles. Materials and Design. 2011;32:133-8.

[27] Afroukhteh S, Dehghanian C, Emamy M. Corrosion behavior of Ni-P/nano-TiC composite coating prepared in electroless baths containing different types of surfactant. Progress in Natural Science: Materials International. 2012;22:480-7.

[28] Muraliraja R, Elansezhian R. Influence of nickel recovery efficiency on crystallinity and microhardness of electroless $\mathrm{Ni}-\mathrm{P}$ coatings and optimisation using Taguchi technique. Transactions of the IMF. 2015;93:126-32.

[29] Karthikeyan S, Ramamoorthy B. Effect of reducing agent and nano Al2O3 particles on the properties of electroless Ni-P coating. Applied Surface Science. 2014;307:654-60.

[30] Muraliraja R, Sendilkumar D, Elansezhian DR. Prediction and Supplementation of Reducing Agent to Improve the Coating Efficiency and Wear Behavior of Electroless Ni-P Plating. Int J Electrochem Sci. 2015;10:5536-47.

[31] Patterson ERMK. Optimization of Reducing Agent and Key Parameters Effect on the Efficiency of Electroless Ni-P Plating by Taguchi Method. Procedia Materials Science. 2014;5:2478-86.

[32] Elansezhian PKNR. Study on characterisation and influence of surfactants on adhesion and coating thickness of electroless Ni-P deposits. International Journal of microstructures and material properties. 2012;7.

[33] Vaezi MR, Sadrnezhaad SK, Nikzad L. Electrodeposition of Ni-SiC nanocomposite coatings and evaluation of wear and corrosion resistance and electroplating characteristics. Colloids and Surfaces A: Physicochemical and Engineering Aspects. 2008;315:176-82.

[34] Schwartz A. Corrosion Prevention By Protective Coatings Second Edition PDF Ebooks-kings.com. 2016:197.

[35] Arenas MF, Reddy RG, Associate R, Professor A. CORROSION OF STEEL IN IONIC LIQUIDS. Journal of Mining and Metallurgy J Min Met. 2003;39:81-91.

[36] Syed S. Atmospheric corrosion of materials. Emirates Journal for Engineering Research. 2006;11:1-24.

[37] Cicek V. Corrosion Engineering. Corrosion Engineering. 2014:1-266.

[38] El-Mahdy GA. Atmospheric corrosion of copper under wet/dry cyclic conditions. Corrosion science. 2005;47:1370-83. 